\title{
EFFECTS OF DIETARY PEAS MIXED WITH LINSEED (3:1) ON THE GROWTH PERFORMANCE, ENTERITIS AND CERTAIN SERUM PARAMETER IN WEANED PIGLETS
}

\author{
Mihaela Hăbeanu*, Nicoleta Lefter, Anca Gheorghe, Cristina Tabuc, Mihaela Dumitru, \\ Georgeta Ciurescu, Mihai Palade \\ National Research Development Institute for Animal Biology and Nutrition (INCDBNA), \\ Calea Bucuresti nr. 1, Balotesti, 077015, Romania
}

\author{
${ }^{*}$ Corresponding author: \\ Phone: +40213512081 \\ Fax: +40213512080 \\ E-mail address: mihaela.habeanu@ibna.ro
}

\begin{abstract}
The objective of this work was to investigate the influence of dietary peas: linseed mixture $(3: 1)$ on the performance and certain serum biochemical parameters of weaned piglets. The faecal bacteriological and fungal composition and diarrhoea incidence was done as well. A total of 20 weaned piglets, $28 \pm 3$ days of age, were assigned randomly to 2 groups: control diet (C diet) with a classical diet (corn and soybean meal) and peas: linseed diet (PL diet, 3:1). The lipid and protein profile were determined by Analyser BS - 130. The cortisol serum concentration was determined with an Immulite 2000 (Siemens). The serum lipase concentration was determined by the spectrophotometer method. The number of microorganisms from the faeces samples was determined by counting the colonies obtained on selected media for each particular microorganism. The dietary addition of peas: linseed mixture did not influence the performance $(P>0.05)$. The serum markers: cholesterol, triglycerides, total protein and their fraction did not differ significantly between treatments. Except the protein, which was slightly under the recommended limit, the other markers were within the physiological limits. The dietary fat content was similar. Serum lipase level in weaned piglets decreased insignificantly by dietary incorporation of peas: linseed $(<9.06 \%$ in $\mathrm{PL}$ diet compared to $\mathrm{C}$ diet). The lower level of serum lipase in PL diet was reflected in a higher level of triglyceride $(>1.10$ times) and cholesterol (>1.06 times). The cortisol level was reduced by $94 \%$ by peas: linseed addition. The vegetable protein source did not have a significant influence on the bacteria of the faeces. After 2 weeks from weaning, the bacteria count was slowly higher in PL diet compared to $C$ diet, as shown by a higher incidence of diarrhoea. We can conclude that peas and linseed are valuable vegetable sources for weaning piglets, their combination delivering an opportunity to have an optimal diet.
\end{abstract}

Key words: peas, linseed, performances, plasma profile, piglets

\section{INTRODUCTION}

Weaning is a difficult period for piglets due to their incomplete development of the enzymatic system and factors generating stress (Kiarie et al., 2007; Habeanu et. al., 2015). The enteric bacterial infections are often treated with antimicrobials but it is important to control the use of antibiotics (Laine et al, 2008). The EU regulation
(2006) regarding clinical using of antibiotics caused an increased interest to develop new solutions (Lallès et al., 2009). Post weaning piglets lose passive intestinal immunity and structure and function of the small intestine are altered (Laine et al, 2008) as well as the intestinal flora is altered (Melin et al., 1997). Escherichia 
coli plays a significant role in the aetiology of intestinal disorder post weaning (Madec et al., 2000). By feeding, it is known that we can reduce the incidence of digestive disorders (Pié et al., 2004).

Weaned piglets are sensitive to the dietary protein (Hermes, 2011; Habeanu et al, 2015). The cheaper source of protein is delivered by plants (soybean, peas, corn gluten etc.). Plant proteins are limited during the first 2 weeks post weaning due to their possible inflammatory effect. However, the plant proteins ensure important amino acids required by the piglet organism (Hermes, 2011).

Peas are characterrized by lower aminoacid content compared to soybean meal, and a lower digestibility of energy than corn (Stein et al., 2004). In growing -finishing pigs there is no limitation on dietary inclusion levels, but in weaned piglets results are less conclusive. Young piglets have a limited capacity to digest fat. Tokach et al. (2003) showed that the dietary fat must have a high quality. Linseed is unique as a vegetable source rich in $\alpha$ linolenic fatty acids (FA) and lignans which have antimicrobial properties (Kiarie et al., 2014). Peas are known to be a valuable alternative to soy-bean meal (Le Gall et al., 2014). A mix between linseed and peas $(1: 3)$ could be a good opportunity to improve energy, amino acids and the fatty acid content of the compound feed.

This work aimed to investigate the influence of dietary peas: linseed mixture (3:1) on performances and some serum biochemical parameters. The health status of weaned piglets reflected in incidence of diarrhoea and bacteria and fungi population of the faeces was determined as well.

\section{MATERIAL AND METHODS}

The feeding trial was conducted on the experimental farm of INCDBNA Balotesti according the Law 43/2014/ Romania.

\section{Animal and diets}

A number of 20 weaning piglets Topigs [ㅇ Large White $x$ Hybride (Large White $x$ Pietrain) $\times 3$ Talent, mainly Duroc], $28 \pm 3$ days of age, $10 q$ and $10 \hat{\sigma}$, were assigned randomly to 2 groups, with two replicates each one: control diet ( $C$ diet) with a classical diet (corn and soybean meal) and peas: linseed diet (PL diet, 3:1). A total of $8 \%$ of peas and linseed mixture replaced $20 \%$ of soybean meal and $6 \%$ of corn grain. The diets (Table 1) were isoenergetic and isonitrogenous, and formulated to meet the requirements of hybrid Topigs.

The feed was given ad libitum in pelletized form, two meals/day. The intake and leftovers were recorded on a daily basis. In order to determine the growth performances, the piglets were weight at weaning and after 20 days.

The linseed used in our study had a high content of oil $(\sim 30 \%)$ and protein $(\sim 20 \%)$, whereas peas had a lower content of oil $(\sim 0.6 \%)$ but a protein level was close to that of the linseed, intermediate between cereals and soybean meal (19\%).

\section{Chemical and biochemical analyses}

Standardized methods, as per Commission Regulation (EC) no. 152 (2009), were used to determine the gross chemical composition of the feed ingredients and of the compound feeds (Habeanu et al., 2015).

The blood samples were collected from 20 piglets by jugular venipuncture (heparinized Vacutainer tubes, Vacutest $\AA$, Arzergrande, Italy) in order to determine the biochemical profile.

The lipid and protein profile were determined by Analyser BS - 130. The cortisol serum concentration was determined by Synevo Romania Laboratory, with an Immulite 2000 (Siemens) which is a solidphase, competitive chemiluminescent enzyme immunoassay, with $1 \times 30$ minutes incubation cycle (Habeanu et al., 2015). The serum lipase concentration was determined by spectrophotometric method.

\section{Analysis of the faeces}

Samples of piglet faeces were collected once a day in Petri dishes, during the experimental period and stored at $-4{ }^{\circ} \mathrm{C}$ until analysed for bacterial and fungal populations. 
The number of microorganisms from the faeces samples was determined by counting the colonies obtained on selected media for each particular microorganism.

The result was expressed as logarithm (base 10) of colony forming units per gram of sample.

Incidence of diarrhoea. The faeces of every piglet were examined visually daily in order to identify the piglets with diarrhoea. We used a subjective scoring system from 1 to 3 to determine the severity of diarrhoea: 1 = soft faeces; 2 = mild diarrhoea; 3 = severe diarrhoea.

The incidence of diarrhoea was calculated as average number of days with diarrhoea related to the total monitoring days.

\section{Statistical analyses and calculation}

The data recorded were expressed as mean values and standard error of the mean (SEM). The data were submitted to variance analysis using SPSS - general linear model (Statistics version 20, 2011). The response to the dietary treatment was variable dependent, and the diet was fixed factor.

The individual was considered as an experimental unit in the case of the serum and performance determinations, while the group was considered as experimental unit in the case of the faeces composition assessing.

Table 1.

Composition of the compound feed (\%)

\begin{tabular}{lcc}
\hline \multirow{2}{*}{ Items, \% } & \multicolumn{2}{c}{ Diets } \\
\cline { 2 - 3 } & Control & Peas: linseed \\
\hline Turda corn & 58.60 & 54.94 \\
Wheat & 10.0 & 10.0 \\
Peas : linseed (3:1) & - & 8.0 \\
Soybean meal & 20.0 & 16.0 \\
Corn gluten & 3.0 & 3.0 \\
Milk replacer & 5.0 & 5.0 \\
Soy oil, Onix variety & 0.05 & - \\
DL-methionine & 0.10 & 0.08 \\
L-lysine & 0.29 & 0.22 \\
Calcium carbonate & 1.70 & 1.55 \\
Phytase & 0.01 & 0.01 \\
Monocalcium phosphate & 0.05 & - \\
Salt & 0.1 & 0.1 \\
Choline premix & 0.1 & 0.1 \\
Vitamin-mineral premix $\ddagger$ & 1.0 & 1.0 \\
\hline
\end{tabular}

Analysed composition (\%)

\begin{tabular}{lcc}
\hline Dry matter & 89.30 & 89.33 \\
ME $(\mathrm{MJ} / \mathrm{kg}) \dagger$ & 3272.1 & 3289.81 \\
Crude protein & 18.85 & 18.32 \\
$\mathrm{PD}$ & 15.35 & 14.71 \\
Lysine & 1.20 & 1.20 \\
Lysine D $\dagger$ & 1.01 & 0.99 \\
Met + Cys & 0.72 & 0.72 \\
Met + Cys D $\dagger$ & 0.6 & 0.59 \\
Calcium & 0.9 & 0.90 \\
Phosphorus & 0.65 & 0.65 \\
Cellulose & 4.15 & 4.61 \\
Ether extracted & 2.4 & 2.8
\end{tabular}

† ME and amino acid contents were calculated based on feed composition. Diets were provided in two meals /day. $D=$ digestible

$\mp$ Vitamin mineral premix added at $1 \%$ to the diet contained (/kg feed): $10000 \mathrm{IU}$ vitamin A; $2000 \mathrm{IU}$ vitamin D3; 30 IU vitamin E; $3 \mathrm{mg}$ vitamin $\mathrm{K} 3 ; 2 \mathrm{mg}$ vitamin B1; $6 \mathrm{mg}$ vitamin B2; $20 \mathrm{mg}$ vitamin B3; $13.5 \mathrm{mg}$ vitamin B5; $3 \mathrm{mg}$ vitamin B6; $0.06 \mathrm{mg}$ vitamin B7; $0.8 \mathrm{mg}$ vitamin B9; $0.05 \mathrm{mg}$ vitamin B12; $10 \mathrm{mg}$ vitamin C; $30 \mathrm{mg}$ of $\mathrm{Mn} ; 110 \mathrm{mg}$ of Fe; $25 \mathrm{mg} \mathrm{Cu} ; 100 \mathrm{mg} \mathrm{Zn;0.38} \mathrm{mg} \mathrm{l;} 0.36 \mathrm{mg} \mathrm{Se} ; 0.3 \mathrm{mg} \mathrm{Co} ; 60 \mathrm{mg}$ antioxidant 


\section{RESULTS AND DISCUSSION}

\section{Animal performance}

Field peas are an important nitrogen and energy source, with a high biological value and digestibility of the protein, low content of fat and antinutritional factors. The results of this study confirm our previous results regarding peas used as alternative source for soybean meal in piglets diets (Habeanu et al., 2009). Due to fat content of the peas, in spite of a valuable fatty acid composition, linseed was included in the diet for its content in polyunsaturated fatty acids, especially n-3.

The growth performances were not significantly affected by applied treatment (Table 2), fact reflected also in the serum biochemical parameters values that were not altered by dietary treatment (Table 3 ).

\section{Serum biochemical profile}

Serum parameters values are markers for health status (Habeanu et al., 2010, 2011; Yeom et al., 2012). The performances of piglets are affected by the metabolic efficiency reflected by level of certain indicators. In our study, the serum indicators (cholesterol, triglycerides, total protein and their fraction: albumin, bilirubin, creatinine and urea) did not differ significantly bet- ween treatments. It is known that a high content of blood cholesterol and triglycerides is associated with an increased risk of body disorders. As shown by the results, the levels of both lipid indicators (cholesterol and triglycerides) were within the normal limits. Whatever the type of marker, the piglets fed with peas: linseed (3:1) had higher value $(P>0.05)$.

Except the protein, slightly below the recommended limit, the other markers were within the physiological limits (Merck\&Co.\&Merial (Firm), 2015; Yeom et al., 2012). Previously, we showed that a lower dietary level of protein reduced piglet post-weaning syndrome associated with the reduced proliferation of pathogen bacteria (Habeanu et al., 2015). The serum protein level could be a result of deficient protein intake.

Urea is the main end product of the nitrogen (Whang \& Easter, 2000) important as marker of piglet's ability to retain nitrogen and use the amino acids. An increased urea:creatinine ratio show us a sign of dehydration, renal dysfunction, protein-rich diet etc. In our study, the ratio was $<20$, whatever the diet, and the values of both indicators were within the range of 1-2.7 $\mathrm{mg} / \mathrm{dL}$ for creatinine and $10-30 \mathrm{mg} / \mathrm{dL}$ for urea concentration.

Table 2.

Changes on weight, gain, feed intake and feed conversion by dietary addition of peas: linseed mixture

\begin{tabular}{lcccc}
\hline Items $^{*}$ & C diet & PL diet & SEM & $\boldsymbol{P ~ v a l u e ~}^{* *}$ \\
\hline Weight at weaning & 6.61 & 6.58 & 0.15 & $N S$ \\
Weight after 20 days & 11.63 & 11.37 & 0.24 & $N S$ \\
ADG & 0.251 & 0.247 & 0.09 & $N S$ \\
ADFI & 0.296 & 0.299 & & \\
g gain: $g$ feed & 0.84 & 0.82 & & \\
\hline
\end{tabular}

${ }^{*} A D G$ average daily gain; $A D F I=$ average daily feed intake

${ }^{*} N S=$ the treatment applied did not influence significantly the performances

Table 3.

Effects of dietary addition of peas:linseed on serum lipids and protein profile

\begin{tabular}{|c|c|c|c|c|c|c|}
\hline \multirow{2}{*}{ Parameters } & \multicolumn{6}{|c|}{ Reference value } \\
\hline & C diet & PL Diet & $\begin{array}{l}\text { Merck, } \\
\text { (2015) }\end{array}$ & $\begin{array}{l}\text { Yeom, } \\
\text { (2012) }\end{array}$ & SEM & $P$ value \\
\hline Cholesterol (mg/dL) & 83.40 & 88.60 & $31-54$ & $59.45-270.3$ & 2.58 & 0.35 \\
\hline $\begin{array}{l}\text { Triglyceride } \\
(\mathrm{mg} / \mathrm{dL})\end{array}$ & 47.45 & 52.55 & $33-50$ & $3-141.45$ & 1.62 & 0.12 \\
\hline Protein (g/dL) & 4.82 & 4.88 & $7.8-8.9$ & $5.07-8.65$ & 0.13 & 0.83 \\
\hline Albumin $(\mathrm{g} / \mathrm{L})$ & 3.54 & 3.87 & $4.2-3.9$ & $3.13-5.03$ & 0.10 & 0.13 \\
\hline Bilirubin (mg/dL) & 0.19 & 0.19 & $0.2-10$ & $0-0.69$ & 0.004 & 0.80 \\
\hline Creatinine (mg/dL) & 1.19 & 1.51 & $1-2.7$ & & 0.10 & 0.14 \\
\hline Urea $(\mathrm{mg} / \mathrm{dL})$ & 16.62 & 17.77 & $10-30$ & & 0.48 & 0.26 \\
\hline
\end{tabular}




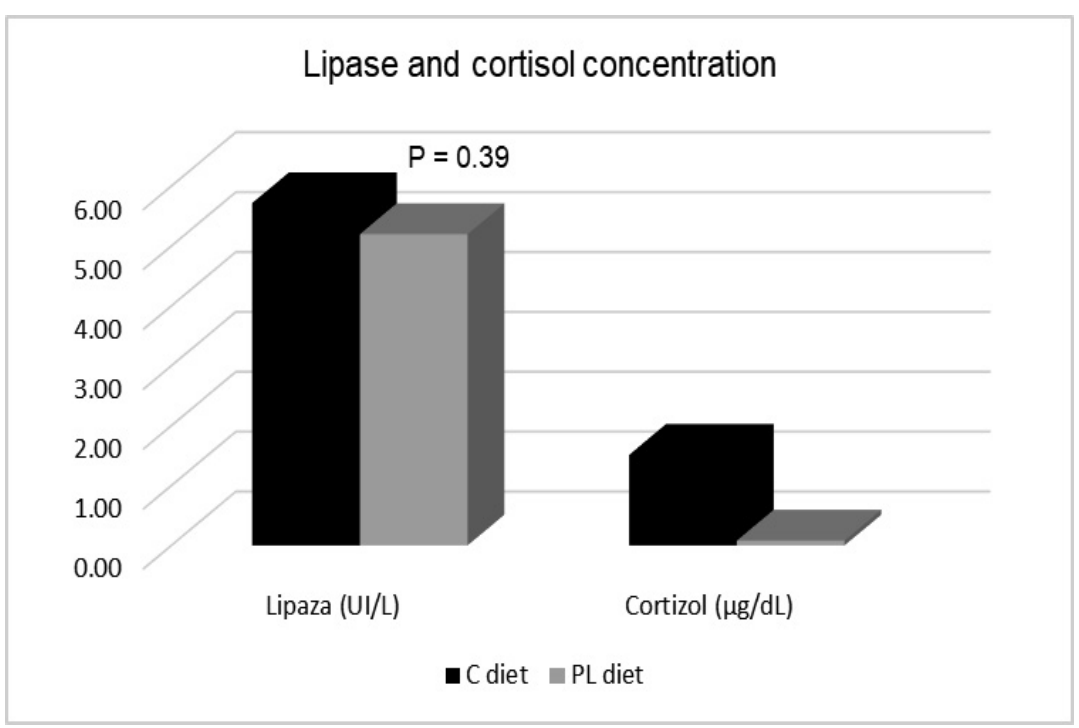

Figure 1. The serum level of lipase and cortisol

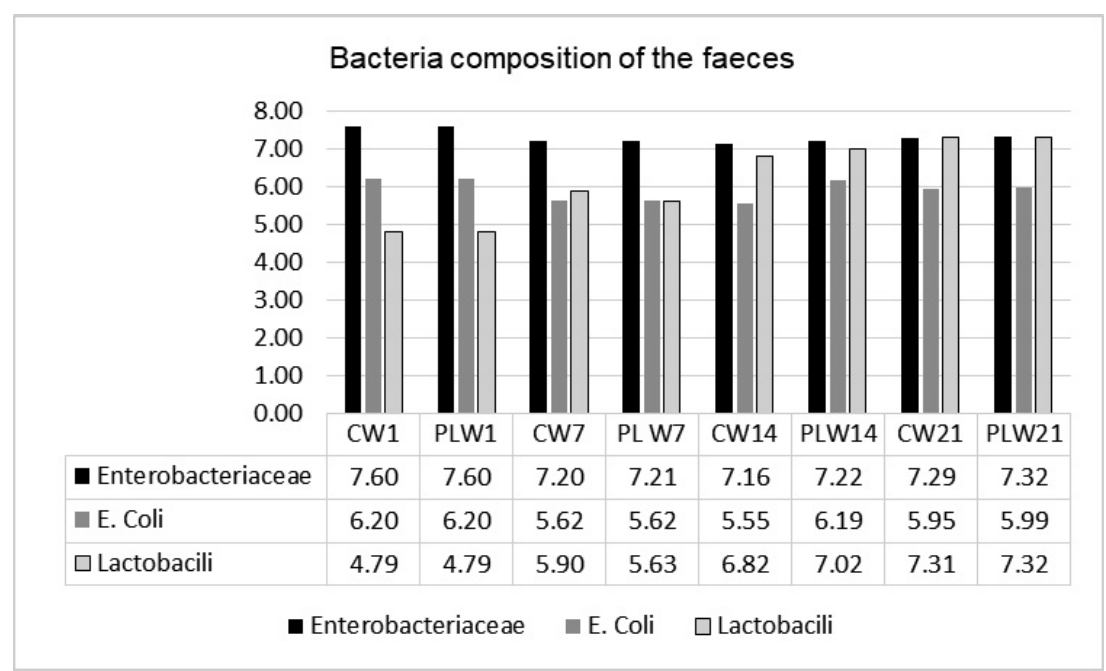

Figure 2. Dynamics of the bacteriological changes in the faeces (lg CFU/g)

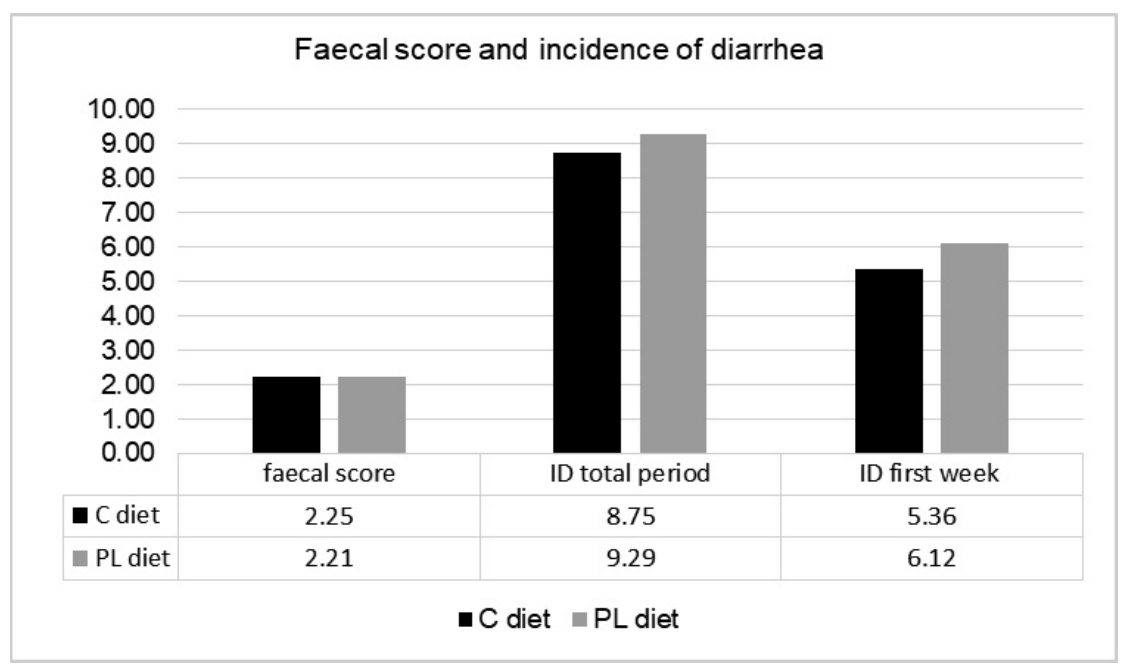

Figure 3. Faecal score, incidence of diarrhoea (ID) during the weaning crises period and in the first week after weaning 
Weaning period is characterized by a decline in the pancreatic enzyme concentration (Marion et al., 2003). The period of time to recover the enzyme content of the pancreas ranges from 2 to 3 weeks post weaning (Marion et al., 2003), and depends on the dry feed intake and protein source. The lipase level also depends on the dietary fat content. In our work the dietary fat level was similar. Serum lipase enzyme level of the weaned piglets decreased insignificantly by dietary incurporation of $8 \%$ peas: linseed $(<9.06 \%$ in $\mathrm{PL}$ diet compared to $\mathrm{C}$ diet, Figure 1). The lipase has an important role in triglycerides hydrolysis (Jensen et al., 1997). The lower level of serum lipase in PL diet was reflected in a higher triglyceride $(>1.10$ times) and cholesterol (>1.06 times) level. A tendency that the treatment had effect was noticed for serum cortisol as stress indicator. The cortisol level was reduced by $94 \%$ by the dietary addition of peas: linseed. At weaning, the level of cortisol specified in literature ranged between 1.7$2.17 \mu \mathrm{g} / \mathrm{dL}$ and $1.68-2.27 \mu \mathrm{g} / \mathrm{dL}, 7$ days after weaning, respectively (Habeanu et al., 2015). In our trial, 20 days after weaning, the cortisol value varied between $0.08-2.89 \mu \mathrm{g} / \mathrm{dL}$. A possible explanation of this variability consists in the correlation between cortisol concentration and the health status of the piglets reflected in the days of diarrhoea.

\section{Faecal bacteriological and fungal com- position and diarrhoea incidence}

Enteric disorders in weaning crises have consequences on mortality and on growth performances for the producer being an important aspect for sector productivity. Enteric E. coli infection usually occurs in the first week post weaning (Fairbrother et al., 2005). These bacteria proliferate rapidly. Due to oxidation, in the post-weaning period, piglet potential to resist to infection caused by $E$. coli bacteria and other factors is affected (Habeanu et al., 2015). Usually, in first days after weaning piglets accumulate fluid in the intestine as sign of dehydration, metabolic acidosis, stress factors and a decreasing of feed intake (Fairbrother and Gyles, 2006). The vegetable protein source didn't have a sig- nificant influence on the bacteriological composition of the faeces (Figure 2).

After 2 weeks from weaning, the bacteria count was slowly higher in PL diet compared to $C$ diet as shown by a higher incidence of diarrhoea (figure 3 ).

The total fungal counts were close between the treatments (4.19 lg CFU/ g in C diet vs. $4.08 \mathrm{lg} \mathrm{CFU} / \mathrm{g}$ in PL diet. Colonies of Fusarium graminearum, F. verticilioides, Penicillium and Yeast were identified. The consistency score was measured on a scale from 1 to 3 : $1=$ soft faeces; $2=$ mild diarrhoea; 3 = severe diarrhoea (figure 3 ). The faecal score was similar between the treatments.

\section{CONCLUSIONS}

Peas and linseed are valuable vegetable sources for weaning piglets, their combination delivering an opportunity to have an optimal diet, balanced in essential nutrients with positive consequences on weaned piglets. The changes on the growth performance and in certain serum biochemical parameters did not differ significantly by dietary addition of peas: linseed. The bacteria counts increased slowly by peas: linseed treatment with consequences on enteric disorder.

\section{ACKNOWLEDGEMENTS}

Financial support for this work was provided by the Romanian Ministry of Research and Innovation (grant PN16410101).

\section{REFERENCES}

1. Fairbrother, J.M., Nadeau, É, Gyles, C.L. (2005). Escherichia coli in post weaning diarrhoea in pigs: an update an bacterial types, pathogenesis and prevention strategies. Animal Health Research Reviews, 6, 17-39.

2. Fairbrother, J.M, Gyles, C.L. (2006). Escherichia coli infections. Diseases of Swine, 639674.

3. Habeanu, M., Hebean, V., Stoica. I. (2009). Enzime furajere, elemente de impact in nutritia suinelor. Editura Ars Academica, Bucuresti.

4. Habeanu, M., Hebean, V., Taranu, I., Marin, D., Lefter, N.A. (2010). Effects of the dietary ecologic camelina oil on blood plasma composition in finishing pigs. XIV International Symposium Feed Technology, Novi Sad, Serbia, Proceedings, pp. 17-23. 
5. Habeanu, M., Hebean, V., Nagy, Al., Taranu, I., Lefter, N.A., Marin, D., Grosu, H. (2011). The dietary omega-3 Pufa alter the metabolic and immunologic serum profile in Mangalitza pigs in rearing extensive system. Archiva Zootechnica, $14(1), 5-12$.

6. Habeanu, M., Lefter, N.A., Gheorghe, A., Tabuc, C., Untea A.E., Surdu, I., Balan, C.G. (2015). Changes in certain serum and faeces parameters in weaned piglets as a response to nutritional stress. South African Journal of Animal Sciences, 45 (2), 164-172.

7. Hermes, R.G. (2011). Natural feeding to reduce enteric disorder and improve adaptation of young pigs to weaning. PhD Thesis. Facultat de Veterinaria de Barcelona. http://www.tesisenred.net.

8. Laine, T.M., Lyytikäinen, T., Yliaho, M., Anttila, M. (2008). Risk factors for post-weaning diarrhoea on piglet producing farms in Finland. Acta Veterinaria Scandinavia, 50 (21), 1-11.

9. Jensen, M.S., Jensen, S.K, Jakobsen, K. (1997). Development of digestive enzymes in pigs with emphasis on lipolytic activity in the stomach and pancreas. Journal of Animal Science, 75, 437-445.

10. Lallès, J.P., Bosi, P, Janczyk, P., Koopmans, S.J. and Tarrallardona, D. (2009). Impact of bioactive substances on the gastrointestinal tract and performance of weaned piglets. A review. Animal, 3 (12), 1625-1643.

11. Le Gall, M., Quillien, L., Sève, B., Guéguen, J., Lallès, J.P. (2014). Weaned piglets display low gastrointestinal digestion of pea (Pissum sativum L.) lectin and pea albumin. Journal of Animal Science, 85, 2972-2981.

12. Kiarie, E., Nyachoty, C.M., Slominski, B.A., Blank, G. (2007). Growth performance, gastrointestinal microbial activity and nutrient digestibility in early-weaned pigs fed diets containing flaxseed and carbohydrase enzyme. Journal of Animal Science, 85, 2982-2993.

13. Madec, F., Bridoux, N., Bounaix, S., Cariolet, R., Duval-Iflah, Y., Hampson, D.J. (2000). Experimental models of porcine post-weaning colibacillosis and their relationship to post-wea- ning diarrhoea and digestive disorders as encountered in the field. Veterinary Microbiology, 72, 295-310.

14. Marion, J, Romé, V., Savary, G.,Thomas, F.,Le Dividich, J., Le Huërou-Luron, I. (2003). Weaning and feed intake alter pancreatic enzyme activities and corresponding mRNA level in 7-d -old piglets. The Journal of Nutrition, 133, 362368.

15. Melin L., Jensen-Waern $M$, Johannisson, A., Ederoth, M., Katouli, M., Wallgren, P. (1997). Development of selected faecal microfloras and of phagocytic and killing capacity of neutrophils in young pigs. Veterinary Microbiology, 54, 287300.

16. Merck \& Co. \& Merial (Firm) (2015). The Merck veterinary manual, Merck \& Co., Inc., Kenilworth, NJ, USA.

17. Pié, S., Lallès, J.P., Blazy, F., Laffitte, J., Sève, B., Oswald, I.P. (2004). Weaning is associated with an upregulation of expression of inflamematory of piglets. The Journal of Nutrition, 134, 641- 647.

18. Stein, H.H., Benzani, G., Botlke, R.A., Peters, D.N. (2004). Assessment of the feeding value of South Dakota - grown field peas (Pissum sativum, L). Journal of Animal Science, 82, 2568-2578.

19. Tokach, M.D., Dritz, S.S., Goodlad R.A., (2003). Nutritional requirements of the weaned pigs. In Weaning the pigs. Concept and consequences. Eds. J.R., Pluscke J., Le Dividich Verstegen M.W.A. Verstegen, Wageningen Academic Publisher, Wageningen, The Nederlands, pp. 259-299.

20. Yeom, S.C., Cho, S.Y., Lee, W.J. (2012). Analysis of reference interval and age-related changes in serum biochemistry and haematology in the specific pathogen miniature pig. Laboratory Animal Research, 28 (4), 245-253.

21. Whang, K.Y., Easter, R.A. (2000). Blood urea nitrogen as an index of food efficiency and lean growth potential in growing - finishing swine. Asian Australian Journal of Animal Science, 13 (6), 811-816. 


\title{
ЕФЕКАТ СМЕСЕ ПРЕХРАМБЕНОГ ГРАШКА И ЛАНЕНОГ СЕМЕНА (3:1) НА ПРОИЗВОДНЕ ПЕРФОРМАНСЕ, ЕНТЕРИТИС И ОДРЕЪЕНЕ ПАРАМЕТРЕ СЕРУМА КОД ОДЛУЧЕНЕ ПРАСАДИ
}

\author{
Михаела Хабеану“, Николета Лефтер, Анка Георге, Кристина Табук, Михаела Думитру, \\ Георгета Цируеску, Михаи Паладе \\ Национални истраживачки развојни институт за биологију и исхрану животиња (INCDBNA), \\ Калеа Букурешти бр. 1, Балотешти, 077015, Румунија
}

Сажетак: Циљ овог рада био је да се истражи утицај смесе прехрамбеног грашка: ланеног семена (3:1) на производне перформансе и одређене биохемијске параметре серума код одлучене прасади. Такође су испитане фекалне бактериолошке и фунгалне културе, као и појава дијареје. Укупно двадесет одлучених прасади старости од $28 \pm 3$ дана било је насумично подељено у две групе: контролна група (Ц дијета) са класичном исхраном (кукуруз и сојина сачма) и огледна друпа (ГЛ дијета 3:1). Липидни и протеински састав утврђен је помоћу уређаја Analyser BS - 130. Концентрација кортизола серума одређена је помоћу уређаја Immulite 2000 (Siemens). Концентрација липазе серума је одређена спекторофотометријском методом. Укупан број микроорганизама у узорку фецеса одређен је методом бројања колонија на одабраним подлогама за сваки микроорганизам. Додавање смесе грашак: ланено семе није значајно утицало на производне перформанце прасади ( $>0,05)$. Маркери серума: холестерол, триглицериди, укупни протеини и њихова фракција се такође нису значајно разликовали између третмана. Осим протеина, чији је садржај био незнатно испод препоручених граница, остали маркери били су у препорученим физиолошким границама. Садржај масти био је сличан код обе групе прасади. Ниво липазе у серуму код испитиване прасади био је нешто мањи у огледној групи у односу на контролну, али разлика није била статистички значајна (<9,06\% у ГЛ дијети у поређењу са Ц дијетом). Нижи ниво липазе серума у огледној групи (ГЛ дијета) огледао се у вишем нивоу триглицерида (> 1,10 пута) и холестерола (> 1,06 пута). Ниво кортизола смањен је за 94\% у огледној групи. Извор биљних протеина није имао значајан утицај на бактерије из фецеса. Након две недеље од одбијања, број бактерија је постепено постајао виши у огледној групи (ГЛ дијета) у поређењу са контролном (Ц дијета), што је показала и већа учесталост дијареје. Може се закључити да грашак и ланено семе представљају драгоцене изворе биљних протеина за одлучену прасад, а њихова комбинација пружа могућност оптимизације исхране.

Кључне речи: грашак, ланено семе, производне перформансе, профрил плазме, прасад

Received: 17 October 2017

Accepted: 17 November 2017 